\title{
SISTEMA PLANTIO DIRETO ORGÂNICO: PRODUTIVIDADE DE MILHO-VERDE EM FUNÇÃO DE DIFERENTES COBERTURAS DE SOLO
}

\author{
Luiz Fernando Favarato ${ }^{1}$ \\ Jacimar Luis de Souza ${ }^{2}$ \\ Rogerio Carvalho Guarçoni ${ }^{3}$ \\ Douglas Vianna Bahiense ${ }^{4}$ \\ André Ângelo Bellon ${ }^{5}$
}

\begin{abstract}
Resumo: O cultivo de diferentes espécies de plantas de cobertura possibilita a melhoria e a conservação do solo e da matéria orgânica, além de promover consideráveis aumentos de rendimento nas culturas subsequentes. Objetivou-se avaliar a produtividade do milho-verde sobre diferentes coberturas de solo no sistema plantio direto orgânico. O trabalho foi desenvolvido no município de Domingos Martins, ES, Brasil. Foi estudada a produtividade de milho verde em função de cinco sistemas de produção, constituídos por três coberturas de solo no sistema plantio direto (SPD) orgânico, com palha de aveia-preta; com palha de tremoço-branco; com palha do consórcio aveia/tremoço e dois sistemas sem palhada e com revolvimento do solo, um orgânico e outro convencional, estes dispostos no delineamento de blocos casualizados, com seis repetições. Foram realizadas avaliações de número total de espigas comerciais, produtividade total de espigas com palha e sem palha, peso médio de espigas com palha e sem palha, produtividade, peso médio e percentual de espigas comerciais, comprimento e diâmetro de espigas comerciais sem palha. O uso de tremoço-branco solteiro ou em consórcio com aveia-preta apresentaram-se proporcionaram produtividade satisfatória para a cultura do milho-verde.
\end{abstract}

Palavras-chave: Zea mays, plantas de cobertura, agricultura orgânica

\footnotetext{
1 Pesquisador/Instituto Capixaba de Pesquisa, Assistência Técnica e Extensão Rural, Brasil. E-mail: Iffavarato@gmail.com.

2 Pesquisador/Instituto Capixaba de Pesquisa, Assistência Técnica e Extensão Rural, Brasil. E-mail: jacimarsouza@yahoo.com.br.

3 Pesquisador/Instituto Capixaba de Pesquisa, Assistência Técnica e Extensão Rural, Brasil. E-mail: rogerio.guarconi@gmail.com.

${ }_{4}$ Bolsista/Instituto Capixaba de Pesquisa, Assistência Técnica e Extensão Rural, Brasil. E-mail: douglas.bahiense@yahoo.com.br.

${ }^{5}$ Assistente de laboratório/Instituto Capixaba de Pesquisa, Assistência Técnica e Extensão Rural, Brasil. E-mail: aa-bellon@hotmail.com.
} 